\title{
Pertumbuhan ikan Nila Larasati (Oreochromis niloticus) di Tambak dengan Pemberian Ransum Pakan dan Padat Penebaran yang Berbeda
}

\author{
Ali Djunaedi1*, Retno Hartati', Rudhi Pribadi1, Sri Redjeki ${ }^{*}$, \\ Retno W. Astuti2 ${ }^{2}$ Bintang Septiarani ${ }^{3}$ \\ 'Departemen IImu Kelautan, Fakultas Perikanan dan IImu Kelautan, Universitas Diponegoro \\ JI. Prof. Soedarto, SH. Kampus UNDIP Tembalang, Semarang 50275 \\ 2Mercy Corps Indonesia \\ 3Yayasan Bintari, Semarang \\ Email: alidjunaedi@ymail.com
}

\begin{abstract}
Red Nile Tilapia of Larasati strain (Oreochromis niloticus)have capability to digest feed quite efficient, able to grow faster and diseases resistant. They are also tolerant to high salinity and more resilent to environmental change, therefore very prospecytive to be cultivated in tambaks (brackishwater pond). The objective of present work was to determine the effect of larvae stocking density and feed ration on the growth and survival rate of Nile Tilapia in brackishwater pond. The larvae was hacthed in freshwater and acclimatized gradually in brackishwater media and then reared ini cage size of $1 \times 1 \times 1,5$ meter $^{3}$ with different food ration (3,5 and 7\% body weight)andstocking density of 10, 15, $\left.20 \mathrm{indv} . / \mathrm{m}^{2}\right)$. The result showed that the more food ration gave the better growth rate of larvae in stocking density of 10 and $15 \mathrm{indv} . / \mathrm{m}^{2}$, the best food ration in $20 \mathrm{indv} . / \mathrm{m}^{2}$ was $5 \%$ body weight. Upon that result it is recommended to stock the alvae at level of $20 \mathrm{indv}$./meter and gave food of $5 \%$ per body weight. The treatments was not influenced the survival rate of fish cultured.
\end{abstract}

Keywords :Fish Nila Larasati, growth, feed ration, stocking density

\section{Abstrak}

Ikan Nila Larasati memiliki kemampuan mencerna makanan secara efisien, memiliki pertumbuhan yang cepat serta lebih resisten terhadap penyakit, daya adaptasi luas dan toleransinya yang tinggi terhadap berbagai kondisi lingkungan sehingga prospektif dibudidaya di tambak. Penelitian ini bertujuan untuk melakukan kajian tentang pengaruh padat tebar dan ransum pakan terhadap pertumbuhan dan kelulushidupan ikan Nila Larasati yang dipelihara pada tambak air payau. Ikan Nila Larasati dibenihkan di lingkungan air tawar dan diaklimatisasi secara bertahap di media air payau sebelum digunakan dalam penelitian ini. Percobaan pemeliharaan ikan Nila Larasati dilakukan pada karamba berukuran $1 \times 1 \times 1,5$ meter $^{3}$ dengan ransum pakan $(3,5$ dan $7 \%$ bobot biomasa ikan) dan padat penebaran yang berbeda $\left(10,15,20\right.$ ekor $\left./ \mathrm{m}^{2}\right)$. Hasil penelitian menunjukkan pemberian ransum pakan harian baik 3, 5 dan $7 \%$ perhari pada ikan nila dengan kepadatan 5, 10 dan 20 ekor/meter menunjukkan hasil pertumbuhan berat mutlak yang relatif baik, namun untuk efisiensi pakan disarankan untuk melakukan penebaran 20 ekor/meter dengan ransum 5\% berat biomasa ikan perhari. Kelulushidupan ikan Nila Larasati tidak dipengaruhi oleh perlakuan.

Kata Kunci : Ikan Nila Larasati , pertumbuhan, pakan, padat penebaran

\section{PENDAHULUAN}

Salah satu jenis komoditas yang potensial dibudayakan di tambak dalam rangka pemanfaatan lahan yang tidak produktif adalah ikan Nila, khususnya Nila Larasati (Oreochromisniloticus). Keunggulan komparatif, terutama pada 
sifat biologis Ikan nila Larasati memiliki beberapa kelebihan seperti mampu mencerna makanan secara efisien, memiliki pertumbuhan yang cepat serta lebih resisten terhadap penyakit, daya adaptasi luas dan toleransinya yang tinggi terhadap berbagai kondisi lingkungan, sehingga ikan ini selain di air tawar, sangat cocok pula dikembangkan di perairan payau (tambak), asin (laut) dengan kisaran salinitas 0-40 ppt (Suyanto, 2009). Selain itu Nila Larasati juga memiliki daging putih yang tebal dan kenyal, yang mirip dengan tekstur ikan kakap merah (Lovell, 1989).

Agar dapat dicapai produksi yang tinggi dan menguntungkan, maka dalam budidaya perlu dilakukan dengan sistem intensif. Menurut Ronald et al. (2014)budidaya intensif dengan menggunakan padat penebaran dan jumlah pakan yang tinggi akan berdampak pada menurunnya kualitas air budidaya dikarenakan semakin bertambahnya tingkat buangan dari sisa pakan dan kotoran (feses). Sedangkan menurut Helpher dan Pruginin (1981), peningkatan kepadatan akan diikuti dengan penurunan pertumbuhan sehingga pada kepadatan tertentu pertumbuhan akan terhenti karena suplai nutrisi sudah tidak mencukupi. Untuk memperoleh hasil yang optimal, peningkatan kepadatan harus juga diikuti dengan peningkatan jumlah pakan. Akan tetapi peningkatan jumlah pakan, akan meningkatkan buangan metabolisme tubuh, konsumsi oksigen dan dapat menurunkan kualitas air. Penurunan kualitas air akan mengakibatkan ikan menjadi stress sehingga pertumbuhan menurun dan ikan rentan mengalami kematian.

Penelitian tentang pengaruh padat penebaran dan pakan terhadap pertumbuhan dan kelulushidupan ikan Nila telah banyak dilakukan oleh beberapa peneliti, akan tetapi kebanyakan dilakukan pada lingkungan air tawar. Penelitian tersebut antara lain adalah tentang kepadatan (Alhassanet al., 2012; Ronald et al., 2014), pakan (Adewolu, 2008; Ogunji et al., 2008), serta kombinasi padat penebaran dan pakan yang berbeda (El-Sayed, 1999;Yakubu et al., 2012). Sedangkan penelitan yang dilakukan pada lingkungan air payau baru dilakukan oleh Clark et al. (1990) yang memelihara ikan Tilapia Merah di kolam air laut dan Mardiana dan Syakirin (2013)yang memelihara berbagai strain ikan Nila dilahan sawah puso akibat rob Desa Pecakaran, Kecamatan Wonokerto, Kabupaten Pekalongan, serta Saha dan Khatun (2014) yang memelihara Tilapia monoseks di tambak udang. Untuk itu penelitian ini bertujuan untuk melakukan kajian tentang pengaruh padat tebar dan ransum pakan terhadap pertumbuhan dan kelulushidupan ikan Nila Larasati yang dipelihara pada tambak air payau.

\section{MATERI DAN METODE}

Benih ikan Nila Larasati berukuran 0,8-1,2gram sebanyak 1000 ekor diperoleh dari BBI Ngrajeg-Janti-Jogjakarta yang diperlihara pada kolam air tawar dan diaklimatisasi pada kondisi perairan payau di Hatchery Laboratorium Ilmu Kelautan, Fakultas Perikanan dan IImu Kelautan, UNDIP Semarang. Penelitian pemeliharaan ikan nila ini dilaksanakan di tambak Desa Mangkang Wetan-Tugu, Semarang pada bulan Januari-April 2015.

Proses aklimatisasi pada media air payau dilakukan pada 5 buah akuarium dengan kepadatan masing-masing 200 ekor. Proses adaptasi salinitas secara bertahap dengan menambahkan air laut pada akuarium tempat penampungan benih sedikit demi sedikit sehingga dicapai kenaikan salinitas 5\% setiap minggu. Adaptasi dilakukan sampai salinitas mencapai 30\% \% menyesuaikan tambak di lokasi penebaran benih. Aklimatisasi dilakukan selama 5 minggu.Pemberian pakan selama aklimatisasi dilakukan dua kali sehari (pagi dan sore hari) sebesar5\% bobot ikan. Pakan yang digunakan adalah pellet ikan mengapung dengan kandungan protein kurang lebih $30 \%$. Selama adaptasi dilakukan pula penyiponan untuk membersihkan sisa pakan dan kotoran/faeses ikan pada pagi hari sebelum diberi pakan. 
Metode penelitian ini adalah
percobaanl
lapangan
dengan Rancangan Acak Lengkap dengan pola faktorial dengan 2perlakuan dan 3 taraf, yaitu ransum pakan yang berbeda $(3,5$ dan $7 \%$ bobot biomasa ikan) dan padat penebaran 10, 15, 20 ekor $/ \mathrm{m}^{2}$, masingmasing dengan 3 ulangan. Pakan yang diberikan berupa pellet ikan komersial yang diperoleh dari BBI Janti Klaten dengan kandungan protein 31-33\%, lemak $4 \%$, serat $5 \%$, kadar abu $13 \%$ dan kadar air $12 \%$. Pakan diberikan 3 kali sehari yaitu pada pagi, siang dan sore hari.

Percobaan pemeliharaan ikan nila dilakukan pada karamba berukuran $1 \times 1 \times 1,5$ meter $^{3}$ di Tambak milik Bapak $\mathrm{H}$. Hambali di Desa Mangkang Wetan. Pemilihan lokasi didasarkan atas pertimbangan kondisi tambak yang relatif baik posisinya serta konstruksinya. Diharapkan kualitas air yang ada bisa mendukung pertumbuhan ikan nila. Posisi penempatan karamba didekat dengan pondok tempat jaga dan dibawah tegakan pohon mangrove dengan pertimbangan supaya karamba ternaungi, sehingga suhu air tidak terlalu tinggi.

Pada awal percobaan, penebaran benih di karamba pemeliharaan dilakukan pada sore hari dengan padat penebaran sesuai perlakukan, yaitu 10,20 , dan 30 ekor $/ \mathrm{m}^{2}$. Pada saat ditebar rata-rata berat ikan nila adalah 3,39gram. Selama penelitian, penimbangan terhadap bobot ikan uji akan dilakukan seminggu sekali, bersamaan dengan pengukuran kualitas air yang meliputi suhu air, oksigen terlarut, $\mathrm{pH}$, dan amonia. Pengukuran suhu air, salinitas, dan $\mathrm{pH}$ menggunakan water quality checker dilakukan bersamaan dengan pengukuran berat tubuh ikan uji.

$\begin{array}{ccc}\begin{array}{c}\text { Variabel yang dikaji meliputi } \\ \text { pertumbuhan } \\ \text { pertumbuhan }\end{array} \text { spesifik } & \text { laju } \\ \text { (SGR), }\end{array}$ kelulushidupan (SR), dan kualitas air sebagai data pendukung. Pertumbuhan berat mutlak dan laju pertumbuhan spesifik (SGR) dihitung berdasarkan (Adewolu, 2008; Ogunji et al., 2008; Effiong et al., 2009) dan Kelulushidupan dihitung berdasarkan Effendie (1997).
Berat mutlak $=\mathrm{L} \dagger-\mathrm{LO}$

$\mathrm{Lt}=$ Berat ikan awal pemeliharaan (gram)

$\mathrm{LO}=$ Berat ikan akhir pemeliharaan (gram)

Laju pertumbuhan spesifik :

$\operatorname{SGR}(\% /$ hari $)=\frac{\mathrm{LnWt}-\mathrm{LnWO}}{\mathrm{T}}$

Wo = Bobot rata-rata benih nila pada awal penelitian (gram)

Wt = Bobot rata-rata benih nila pada hari ke-t (gram)

$\mathrm{T}=$ Lama pemeliharaan (hari).

Kelulushidupan (Survival Rate):

$\mathrm{SR}=\mathrm{NT} / \mathrm{No} \times 100 \%$

$\mathrm{SR}=$ Kelulushidupan (\%)

$\mathrm{Nt}=$ Jumlah ikan pada akhir penelitian (ekor)

No $=$ Jumlah ikan pada awal penelitian (ekor)

Data yang diperoleh terlebih dahulu dilakukan uji $F$ (ragam) dengan taraf kepercayaan $95 \%$. Bila perlakuan berpengaruh nyata pada analisis ragam (ANOVA) (Steel dan Torrie, 1980).

\section{HASIL DAN PEMBAHASAN}

Ikan Nila (Oreochromis niloticus) sudah dikenal sebagai ikan konsumsi air tawar oleh masyarakat sehingga tingkat penerimaan konsumen akan mudah. Ikan Nila bersifat eurihaline (Suyanto, 2009) yang menyebabkan ikan Nila dapat hidup di dataran rendah yang berair tawar hingga perairan bersalinitas tinggi. Semarang merupakan kota pesisir yang memilki potensi dikembangkan untuk budidaya perikanan. Tingginya tingkat kerusakan di wilayah pesisir, secara langsung maupun tidak langsung berdampak terhadap keberlanjutan kegiatan budidaya ikan. Solusi yang cukup efektif untuk diterapkan dalam menjaga keberlanjutan budidaya serta memperbaiki kualitas lingkungan pesisir adalah dengan penerapan tambak wanamina yaitu budidaya ikan pada tambak bervegetasi mangrove (Budihastuti, 2013) dan menyarankan jenis kultivan ikan bandeng dan ikan nila. 
Budidaya Ikan Nila juga disarankan oleh Pribadi et al. (2013) dengan hasil kajiannya untuk mengidentifikasi ikan yang tahan terhadap salinitas dan temperatur tinggi di wilayah pesisir.Ikan Nila Larasti merupakan benih hibrid generasi ketiga hasil persilangan induk ikan Nila betina strain Gift dengan induk jantan strain Singapura pada kegiatan pemuliaan ikan Nila di Satuan Kerja Perbenihan dan Budidaya Ikan Air Tawar Janti - Klaten(Satker PBIAT, 2009) yang merupakan strain terbaik setelah melalui uji pertumbuhan, multi lokasi, salinitas, dan hama penyakit. Berdasarkan penelitianMardiana dan Syakirin (2013) ikanNilastrain Larasatiyang dipelihara pada karamba di sawah yang tidakproduktifakibat rob mempunyaipertumbuhantertinggi dibandingkan denganikanstrain lain, yaitu NilaGiftdan Sultana.

\section{Adaptasi benih ikan Nila Larasati pada media air payau}

Pada percobaan ini, sebelum dibudidayakan di tambak, ikan Nila Larasati yang dibenihkan di lingkungan air tawar diaklimatisasi pada media berair payau secara bertahap (kenaikan $5 \%$ per minggu). Ikan Nila adalah salah satu jenis ikan yang termasuk bersifat eurihaline. Ikan eurihaline merupakan ikan yang memiliki kemampuan besar untuk mentoleransi perubahan salinitas medium dengan rentang yang luas (Susilo, 2012). Hasil pertumbuhan benih ikan nila yang telah dilakukan menunjukkan bahwa pertumbuhan ikan nila selama adaptasi salinitas berkisar antara 1,0-1,2 gr perminggu dari berat awal 1,5 gram. Pertumbuhan benih tersebut tergolong masih relatif rendah, hal tersebut diduga dikarenakan karena energi pakan yang masuk banyak digunakan untuk adaptasi lingkungan terutama penaikan salinitas, sehingga pertumbuhannya belum bisa maksimal.

Pertumbuhan ikan dipengaruhi oleh beberapa faktor antara lain pakan, wadah budidaya, suhu, salinitas, musin dan aktivitas fisik. Karena ikan bersifat poikilothermal dan hidup di air, maka sangat dipengaruhi oleh media budidaya (Weatherly and Gill, 1987). Perubahan kondisi media, misalnya salinitas akan berpengaruh terhadap tubuh ikan yang dipelihara. Pemeliharaan ikan Nila Larasati yang berasal perairan tawar ke perairan payau (tambak) akan mempengaruhi pertumbuhan dan rasa dari ikan tersebut. Hal yang sama dilakukan oleh Ali et al. (2005) dalam penelitiannya memelihara ikan Catla catla, Cirrhinus mrigala, Cyprinus carpio, Hypophthalmicthys molitrix, Labeo rohitayang merupakan ikan air tawar di lingkungan air payau dan menemukan bahwa variable kondisi media payau berpengaruh terhadap pertumbuhan dan komposisi nutrient tubuh seperti kadar air, bahan organik, protein dan lipid. Hal ini berhubungan erat dengan adaptasi fisiologis pada saat beraklimatisasi pada tambak air payau. Secara langsung, salinitas media akan mempengaruhi tekanan osmotik cairan tubuh ikan. Apabila osmotik lingkungan (salinitas) berbeda jauh dengan tekanan
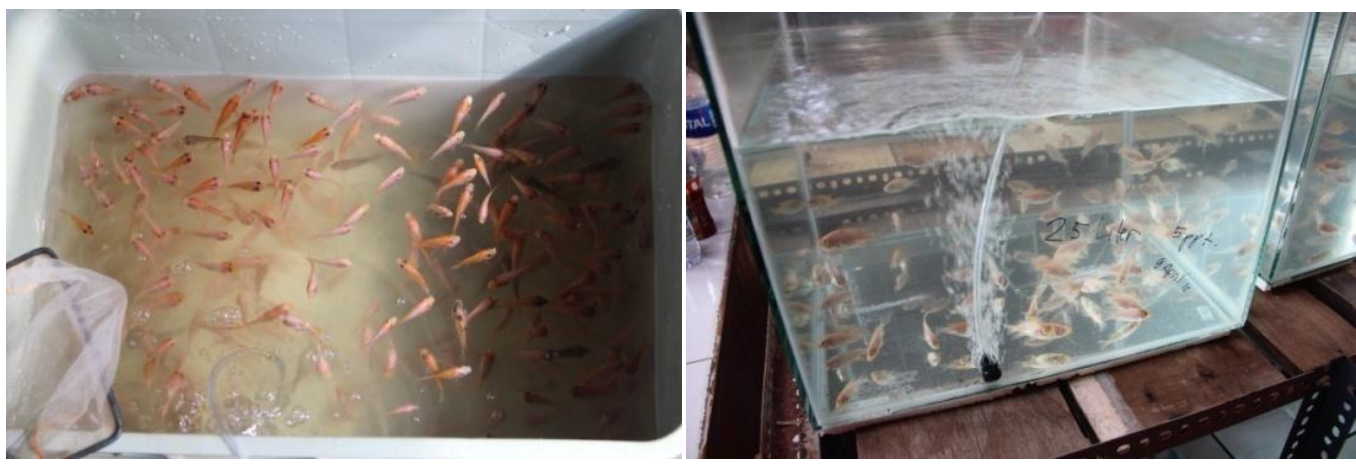

Gambar 1. Proses adaptasi benih pada media air payau 


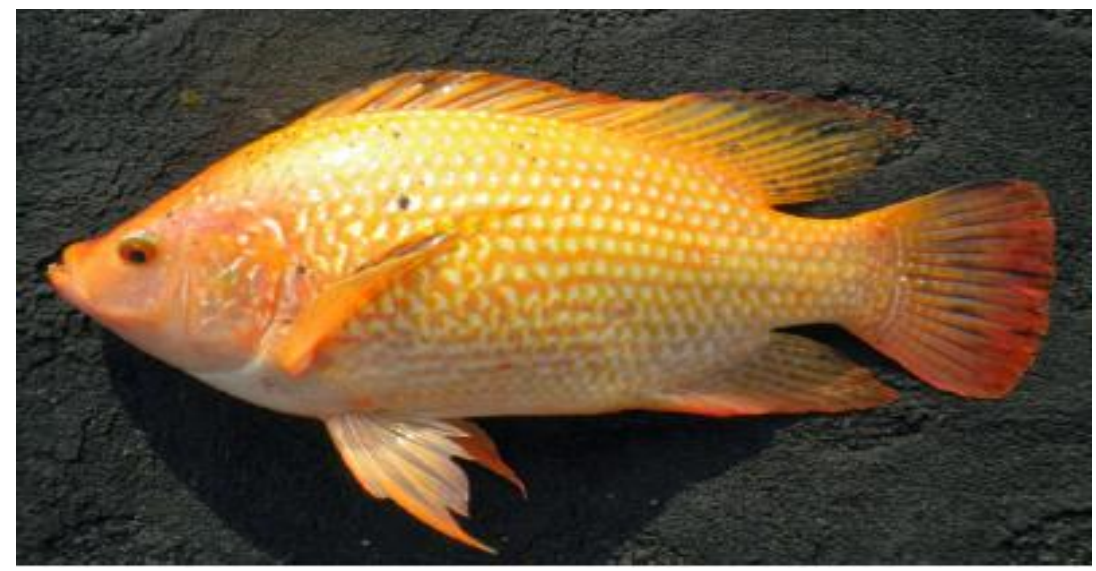

Gambar 2. Ikan Nila Larasati (Oreochromis niloticus) yang digunakan pada penelitian

osmotik cairan tubuh (kondisi tidak ideal) maka osmotik media akan menjadi beban bagi ikan sehingga dibutuhkan energi yang relatif besar untuk mempertahankan osmotik tubuhnya agar tetap berada pada keadaan yang ideal. Pembelanjaan energi untuk osmoregulasi, akan mempengaruhi tingkat konsumsi pakan dan konversi menjadi berat tubuh (Sharaf et al., 2004).

\section{Pertumbuhan ikan Nila Larasati di tambak}

Pada penelitian ini, setelah mengalami masa aklimatisasi, ikan Nila Larasati dipindah dan dibudidayakan pada tambak air payau dengan salinitas 20-33\%. Keberhasilan adaptasi salinitas ditunjukkan oleh kelangsungan hidup yang tinggi dan pertumbuhan yang normal. Dalam kondisi lingkungan yang buruk, ikan membutuhkan energi lebih dalam bentuk ATP yakni senyawa biokimia berenergitinggi yang langsung dapat digunakan untuk energi sel (Uchida et al., 1997).

Intensifikasi budidaya ikan Nila adalah solusi yang baik untuk meningkatkan produksi ikan, danuntuk mengoptimalkan intensifikasi ikan, maka padat penebaran dan kualitas serta kuantitas pakan harus dipertimbangkan. Pakan buatan memainkan peran penting terutama dalam kondisi padat penebaran yang tinggi dan ketika pasokan pakan alami telah menurun atau benar-benar menghilang. Pakan yang ditambahkan harus kaya protein, karbohidrat dan lemak, dan juga harus mengandung vitamin, mineral sehingga menjamin pertumbuhan ikan yang dibudidaya (Huisman et al., 1979). Malnutrisi pada ikan akan mengurangi kinerja pertumbuhan dan dapat menyebabkan penyakit atau bahkan kematian (Lovell, 1989). Sehingga sangat penting untuk mengembangkan pakan yang cocok dalam budidaya ikan sebagai penyeimbang padat penebaran ikan budidaya.

Padat penebaran merupakan hal yang sangat penting untuk dipertimbangkan pada usaha budidaya ikan karena akan mempengaruhi pertumbuhan (Papst et al. (1992) . Hal ini akan dipengaruhi oleh beberapa faktor, seperti interaksi sosial antar ikan (Irwin et al., 1999; Silva et al., 2000), persaingan pakan dan ruang gerak (Papst et al., 1992). Lebih lanjut, menurut Lovell (1989) pertumbuhan Tilapia/Nila dipengaruhi oleh padat penebaran, kualitas proteindan kandungan energi pakan, kondisi fisiologis ikan, seperti umur, tahap reproduksi dan faktor lingkungan seperti salinitas, suhu dan lain-lain.

Pada penelitian ini, pertumbuhan ikan nilai pada kepadatan $10 \mathrm{ekor} / \mathrm{m}^{2}$ dengan pemberian jumlah pakan yang berbeda memberikan hasil sedikit variasi, yaitu berkisar 19,71-21 gram (Tabel 1). Semakin tinggi jumlah pemberian pakan memberikan laju pertumbuhan yang lebih cepat. 
Tabel 1 diatas menunjukkan bahwa pemberian pakan dengan prosentase ransum harian berbeda pada ikan nila dengan kepadatan 10 ekor/meter menghasilkan berat ikan yang dipelihara selama 4 minggu menghasilkan pertumbuhan yang relatif baik. Pertumbuhan paling tinggi dicapai pada pemberian pakan dengan ransum $7 \%$ perhari yaitu 21,00 gram dengan laju pertumbuhan $6,08 \%$ /hari. Sedangkan pertumbuhan yang rendah terjadi pada perlakuan dengan pemberian ransum pakan $3 \%$ perhari yaitu 19,71 gram, namun hasil analisis statistik menunjukkan tidak ada perbedaan yang nyata $(p>0,05)$ antar perlakuan (Gambar 3).

Pemberian pakan yang berbeda pada ikan Nila dengan kepadatan 15ekor/meter menunjukkan hasil yang hampir sama dengan kepadatan 10ekor/meter (Tabel 2). Semakin tinggi jumlah pemberian pakan memberikan pertumbuhan yang sedikit lebih tinggi pertumbuhannya.

Tabel 2 diatas menunjukkan bahwa pemberian pakan dengan prosentase ransum harian berbeda pada ikan nila dengan kepadatan 15 ekor/meter menghasilkan yang dipelihara selama 4 minggu menghasilkan pertumbuhan yang relatif baik. Pertumbuhan paling tinggi dicapai pada pemberian pakan dengan ransum $7 \%$ perhari yaitu 20,91 gram. Sedangkan pertumbuhan yang rendah terjadi pada perlakuan dengan pemberian ransum pakan 3\% perhari yaitu 18,40 gram. Hasil analisis statistik menunjukkan tidak ada perbedaan yang nyata $(p>0,05)$ antar perlakuan. Untuk lebih Jelasnya dapat dilihat pada Gambar 4 dibawah ini. Sedangkan pertumbuhan ikan nila pada padat penebaran 20 ekor/meter disajikan pada Tabel 3.

Tabel 3 diatas menunjukkan bahwa pemberian pakan dengan prosentase ransum harian berbeda pada ikan nila dengan kepadatan 20 ekor/meter menghasilkan yang dipelihara selama 4 minggu menghasilkan pertumbuhan yang relatif baik. Pertumbuhan paling tinggi dicapai pada pemberian pakan dengan ransum 7\%/hari yaitu 20,55 gram. Sedangkan pertumbuhan yang rendah terjadi pada perlakuan dengan pemberian ransum pakan $3 \%$ perhari yaitu 18,78 gram. Hasil analisis statistik menunjukkan tidak ada perbedaan yang nyata $(p>0,05)$ antar perlakuan (Gambar 5).

Pengukuran parameter lingkungan, yaitu salinitas, suhu dan $\mathrm{pH}$ dilakukan selama masa pemeliharaan Ikan Nila di tambak. Kondisi salinitas di tambak pemeliharaan ikan nila relatif tinggi yaitu berkisar 29-34\% (Tabel 4). Hal tersebut disebabkan pada waktu tebar pada kondisi musim kemarau, sedangkan tambak tidak ada sumber air tawar untuk menurunkan salinitas media pemeliharaan. Suhu pada pagi hari berkisar dari $24-25^{\circ} \mathrm{C}$ dan pada sore hari berkisar $30-31^{\circ} \mathrm{C}$. Kisaran suhu tersebut masih layak untuk mendukung kehidupan ikan Nila Larasati. Sedangkan nilai $\mathrm{pH}$ adalah 8 yang juga menunjukkan layak untuk pertumbuhan ikan Nila Larasati.

Tabel 1. Rata-rata berat dan Pertumbuhan Ikan Nila di tambak dengan kepadatan 10 ekor/meter

\begin{tabular}{|c|c|c|c|c|c|c|c|}
\hline \multirow{2}{*}{ \% Pakan } & \multicolumn{5}{|c|}{ Rata-rata berat (gram) Minggu ke - } & \multirow{2}{*}{$\begin{array}{l}\text { Pertumbuhan } \\
\text { (gram) }\end{array}$} & \multirow{2}{*}{$\begin{array}{l}\text { Laju pertubuhan } \\
\text { (\%/hari) }\end{array}$} \\
\hline & 0 & 1 & 2 & 3 & 4 & & \\
\hline 3 & 3,39 & 3,8 & 9 & 14,22 & 19,71 & 16,32 & 5,87 \\
\hline 5 & 3,39 & 4 & 9,67 & 15,13 & 20,75 & 17,36 & 6,04 \\
\hline 7 & 3,39 & 3,86 & 9,63 & 15,13 & 21 & 17,61 & 6,08 \\
\hline
\end{tabular}




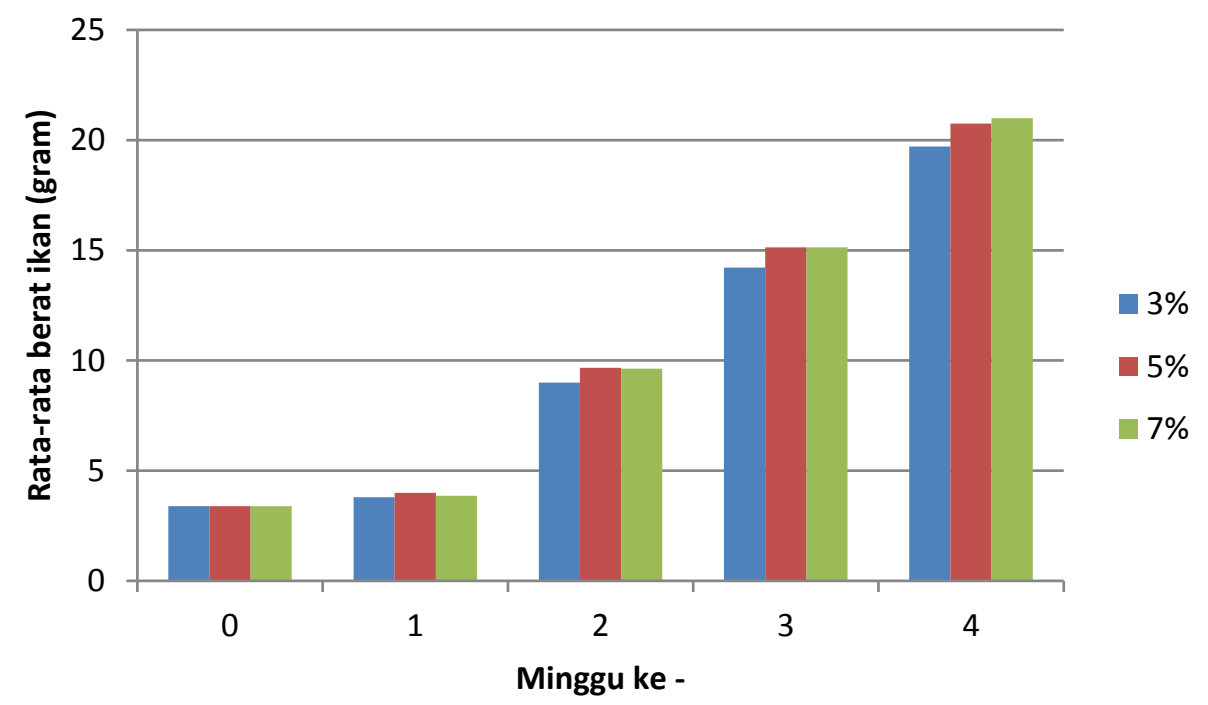

Gambar 3. Pertumbuhan Ikan Nila pada padat penebaran 10 ekor/meter dengan jumlah pakan yang berbeda $(3,5$ dan $7 \%$ berat ikan/hari)

Tabel 2. Rata-rata berat dan Pertumbuhan Ikan Nila di tambak dengan kepadatan 15 ekor/meter

\begin{tabular}{|c|c|c|c|c|c|c|c|}
\hline \multirow{2}{*}{ \% Pakan } & \multicolumn{5}{|c|}{ Rata-rata berat (gram) Minggu ke - } & \multirow{2}{*}{$\begin{array}{l}\text { Pertumbuhan } \\
\text { (gram) }\end{array}$} & \multirow{2}{*}{$\begin{array}{c}\text { Laju pertubuhan } \\
\text { (\%/hari) }\end{array}$} \\
\hline & 0 & 1 & 2 & 3 & 4 & & \\
\hline 3 & 3,39 & 3,64 & 8,50 & 13,40 & 18,40 & 15,01 & 5,64 \\
\hline 5 & 3,39 & 4,11 & 9,50 & 14,80 & 20,20 & 16,81 & 5,95 \\
\hline 7 & 3,39 & 3,78 & 9,50 & 15,27 & 20,91 & 17,52 & 6,06 \\
\hline
\end{tabular}

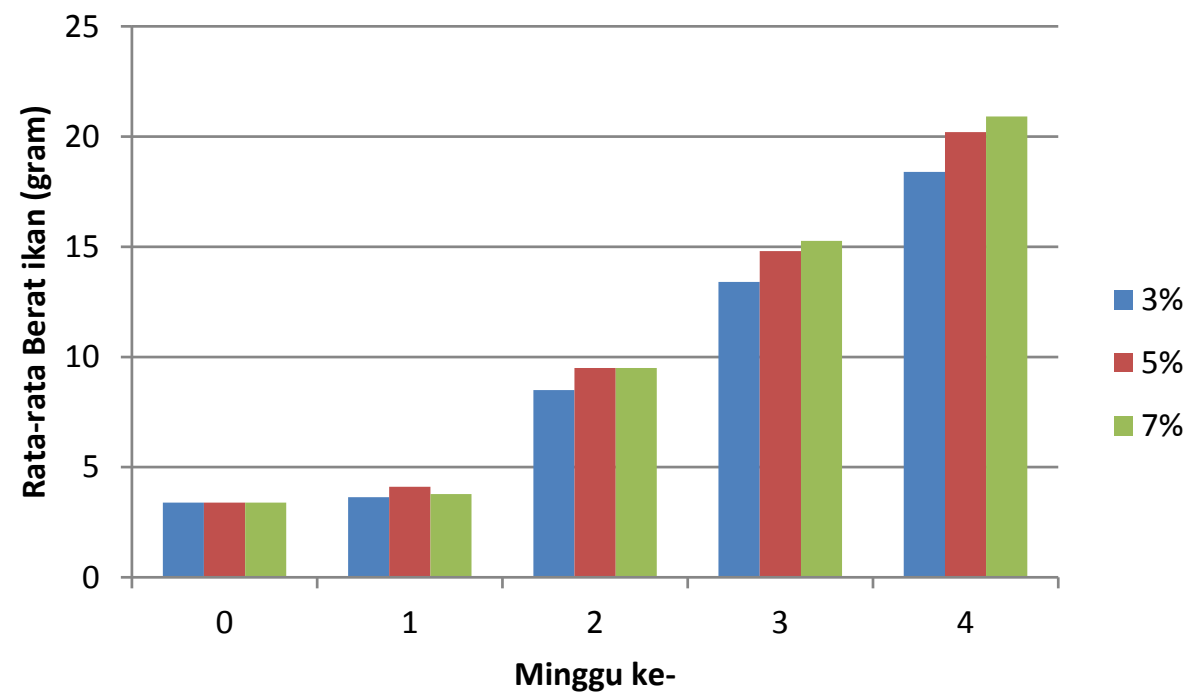

Gambar 4. Pertumbuhan Ikan Nila pada padat penebaran 15 ekor/meter dengan jumlah pakan yang berbeda (3,5 dan $7 \%$ berat ikan/hari) 
Tabel 3. Rata-rata berat dan Pertumbuhan Ikan Nila di tambak dengan kepadatan 20 ekor/meter

\begin{tabular}{|c|c|c|c|c|c|c|c|}
\hline \multirow{2}{*}{ \% Pakan } & \multicolumn{5}{|c|}{ Rata-rata berat (gram) Minggu ke - } & \multirow{2}{*}{$\begin{array}{l}\text { Pertumbuhan } \\
\text { (gram) }\end{array}$} & \multirow{2}{*}{$\begin{array}{l}\text { Laju pertubuhan } \\
\text { (\%/hari) }\end{array}$} \\
\hline & 0 & 1 & 2 & 3 & 4 & & \\
\hline 3 & 3,39 & 3,67 & 8,73 & 13,64 & 18,78 & 15,39 & 5,71 \\
\hline 5 & 3,39 & 4 & 9,73 & 14,92 & 21,27 & 17,88 & 6,12 \\
\hline 7 & 3,39 & 4 & 9,45 & 15,09 & 20,55 & 17,16 & 6,01 \\
\hline
\end{tabular}

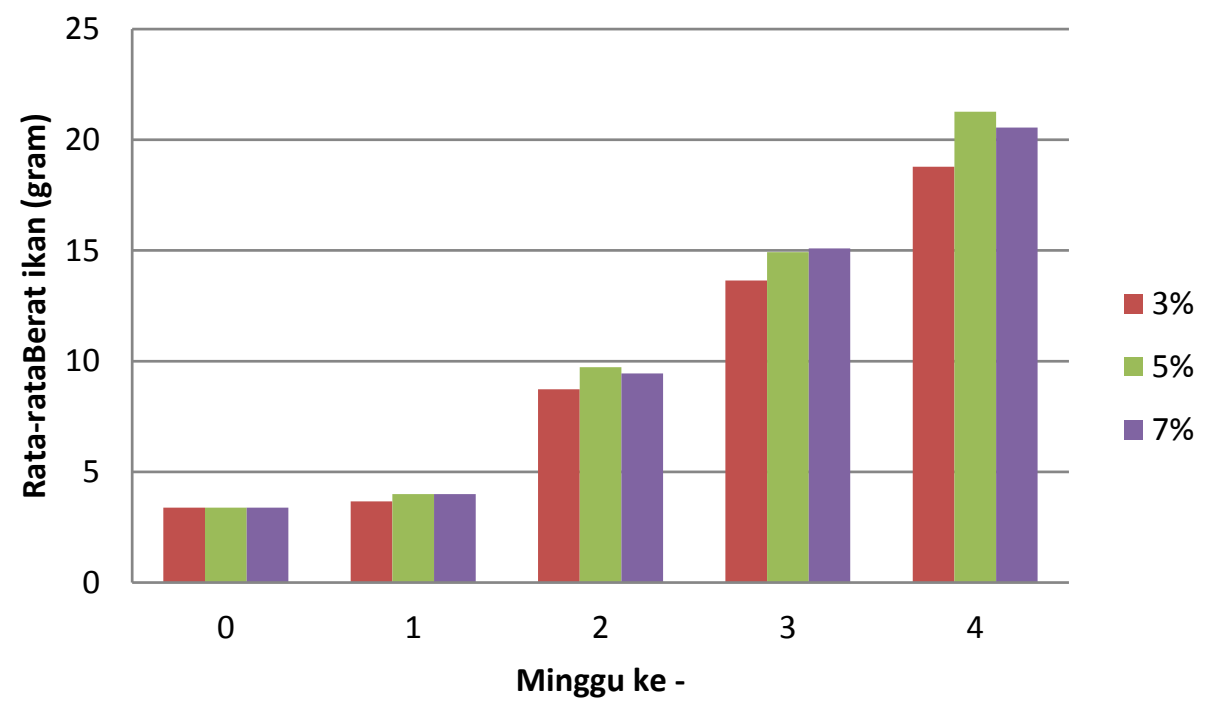

Gambar 5. Pertumbuhan Ikan Nila pada padat penebaran 20 ekor/meter dengan jumlah pakan yang berbeda $(3,5$ dan $7 \%$ berat ikan/hari)

Tabel 4. Nilai rata-rata parameter kualitas air tambak pemeliharaan ikan Nila Larasati

\begin{tabular}{ccccc}
\hline \multirow{2}{*}{ Minggu ke } & Salinitas $(\%$ \%o) & \multicolumn{2}{c}{ Suhu $\left({ }^{\circ} \mathrm{C}\right)$} & $\mathrm{pH}$ \\
\cline { 3 - 4 } & & pagi & sore & \\
\hline 1 & 29 & 25 & 31 & 8 \\
2 & 32 & 24 & 30 & 8 \\
3 & 30 & 25 & 30 & 8 \\
4 & 34 & 25 & 31 & 8 \\
\hline
\end{tabular}

Hasil penelitian menunjukkan bahwa pemberian ransum pakan harian baik 3, 5 dan $7 \%$ bobot ikan per hari pada ikan Nila Larasati dengan kepadatan 5, 10 dan 20 ekor/meter menunjukkan hasil pertumbuhan berat mutlak yang relatif baik. Hal tersebut menunjukkan bahwa ransum pakan yang diberikan mampu memberikan energi yang dibutuhkan untuk pertumbuhan ikan nila di tambak. Huisman et al. (1979) menyatakan bahwa salah satu yang mempengaruhi pertumbuhan adalah pakan dan pemberian pakan yang berkualitas baik dapat menunjang pertumbuhan ikan. Sedangkan pakan yang digunakan adalah pakan ikan dengan kandungan protein $30 \%$, kandungan protein tersebut 
telah mencukupi kebutuhan nutrisi ikan Nila Larasati. Pakan yang sesuai dengan kebutuhan nutrisi ikan terutama protein serta sesuai dengan sifat dan kebiasaan makan ikan dapat meningkatkan efisiensi pakan (Nofyan, 2005). Dikatakan Ali et al. (2005) pertumbuhan ikan pada tambak dipengaruhi oleh interaksi berbagai faktor seperti makanan, ruang, suhu, salinitas, musim dan aktifitas fisik.

Hasil penelitian ini menunjukkan bahwa perbedaan padat penebaran tidak berpengaruh terhadap pertumbuhan mutlak dan laju pertumbuhan Ikan Nila Larasati di tambak air payau. Hasil yang sama juga diperlihatkan oleh penelitian Alhassan et al. (2012) yang memelihara benih ikan Nila pada hapa di dalam kolam beton dengan media air tawar dengan kepadatan 8, 10 and 12 ekor/m³. Pada penelitiannya tersebut konversi pakan, laju pertumbuhan dan kelangsungan hidup ikan nila tidak dipengaruhi oleh padat penebaran yang berbeda. Bahkan padat penebaran yang semakin tinggi menyebabkan pertumbuhan yang heterogen sehingga berat ikan nila yang diperlihara menjadi sangat bervariasi.

Laju pertumbuhan Ikan Nila Larasari yang dipelihara di tambak berkisar 5,64$6,12 \%$ /hari. Hasil ini cukup baik dibandingan dengan pertumbuhan Tilapia monosex yang dibudidaya di tambak udang dengan laju pertumbuhan 6.73\%/hari (Saha dan Khatund, 2014).Pada pemeliharaan ikan Nila Larasati di tambak sebaiknya digunakan monoseks jantan untuk mendapatkan pertumbuhan yang lebih baik. Pertumbuhan ikan Nila jantan dua kali lebih cepat dari ikan betina. Bahkan kehadiran ikan nila betina menyebabkan reproduksi yang tidak terkendali, terjadinya rekrutmen benih yang berlebihan, kompetisi makanan, dan produksi ikan yang lebih kecil dari yang ditebar sehingga mungkin tidak mencapai ukuran konsumsi yang dikehendaki. Hasil penelitian Saha dan Khatund (2014) memperlihatkan bahwa pada pemeliharan di tambak air payau pertumbuhan dan produksi Tilapia monoseks lebih tinggi dibandingkan dengan pemeliharaan di air tawar, dan dianjurkan pula bahwa ikan tersebut dapat di budidaya sebagai diversifikasi biota budidaya di tambak air payau, dimana budidaya udang saat inio sangat beresiko terkena invasi penyakit.

Dari hasil kajian ini, meskipun kelangsungan hidup tidak dipengaruhi oleh padat penebaran ( $P>0.05$ ) (Tabel 4), namun secara umum kelangsungan hidup ikan Nila Larasati yang dipelihara cukup tinggi, yaitu berkisar antara $83-89 \%$ dan tidak berlawanan dengan padat penebaran. Tingginya kelangsungan hidup ikan Nila Larasati yang dipelihara selain didukung oleh kondisi lingkungan tambak yang baik selama penelitian, Hal ini sama dengan hasil penelitan Huang dan Chiu (1997), El-Sayed (1999), El-Sherif dan El-Feky (2009) dan Alhassan et al. (2012) dengan kelulushidupan 83-100\%.

Perairan pesisir merupakan wilayah yang memiliki kerentanan tinggi terhadap aliran antropogenik yang berasal dari limbah aktivitas manusia di wilayah sekitar pesisirmaupun lahan atas. Pesisir Semarang merupakan salah satu wilayah di pesisir utaraJawa yang perkembangan tata guna lahannya sangat progresif (Rositasari dan Lestari, 2013). Peran vegetasi mangrove yang berada dipertambakan sangat berpotensi utnuk menyerap limbah-limbah tersebut mengingat bahwa salah satu peran mangrove adalan sebagai penyerap berbagai limbah di wilayah pesisir.

Kariada dan Irsadi (2014) mengatakan bahwa mangrove berperan sebagai penampung terakhir bagi limbah yang terbawa aliran sungai dari industri di

Tabel 4. Kelulushidupan Ikan Nila Larasati yang dipelihara di tambak dengan kepadatan dan ransum pakan yang berbeda

\begin{tabular}{cccc}
\hline$\%$ & \multicolumn{3}{c}{ Padat penebaran (ekor/meter) } \\
\cline { 2 - 4 } Pakan & 10 & 15 & 20 \\
\hline 3 & 85 & 87 & 83 \\
5 & 87 & 86 & 86 \\
7 & 89 & 84 & 85 \\
\hline
\end{tabular}


perkotaan dan perkampungan hulu dan mengurangi resiko masuknya limbah ke wilayah pertambakan (Heriyanto dan Subiandono, 2011).Oleh karena itu, budidaya ikan nila di tambak bervegetasi mangrove akan mengurangi resiko adanya serapan limbah pada ikan yang dibudidaya.

\section{KESIMPULAN}

Pemberian ransum pakan harian baik $3 \%, 5 \%$ dan $7 \%$ perhari pada ikan nila dengan kepadatan 5, 10 dan 20 ekor/meter menunjukkan hasil pertumbuhan berat mutlak yang relatif baik, namun untuk efisiensi pakan disarankan untuk melakukan penebaran 20 ekor/meter dengan ransum 5\% berat biomasa ikan perhari. Kelulushidupan ikan Nila Larasati tidak dipengaruhi oleh perlakuan.

\section{UCAPAN TERIMAKASIH}

Penelitian ini merupakan bagian dari kegiatan Enhancing coastal community resilience by strengthening mangrove ecosystem services and developing sustainable livelihoods in Semarang City yang dibiayai oleh Rockeffeler Foundation.

\section{DAFTAR PUSTAKA}

Adewolu, M.A. 2008. Potentials of sweet potato (Ipomoea batatas) leaf meal as dietary ingredient for Tilapia zillii fingerlings. Pak. J. Nutr., 7(3): 444-449.

Alhassan, E.H., E.D. Abarike \& C.L. Ayisi. 2012.Effects of stocking density on the growth and survival of Oreochromis niloticus cultured in hapas in a concrete tank. African Journal of Agricultural Research 7(15): 2405$2411 ; \mathrm{m}$. DOI: 10.5897/AJAR11.2313

Ali, M., F. Iqbal, A. Salam, S. Iram, \& M. Athar, 2005. Comparative study of body composition of different fish speciesm from brackish water pond. Int. J. Environ. Sci. Tech. 2( 3): 229-232

Clark, A.E., W.O. Watanabe, B.Olla, \&R.I. Wicklund. 1990. Growth, feed conversion and protein utilization of Florida red tilapia fed isocaloric diets with different protein levels in seawater pools. Aquacult. 88(1): 7585. doi:10.1016/0044-8486(90)90321-D

Effiong, B.N., Sanni, A, \&Fakunle J.O. 2009. Effect of partial replacement of fishmeal with duckweed (Lemna pauciscostata) meal on the growth performance of Heterobranchus longifilis fingerlings. Report and Opin., $1(3): 76-81$

Effendie, M.I. 1997. Biologi Perikanan. Cetakan Pertama. Yayasan Pustaka Nusantara, Yogyakarta

El-Sayed, A. 1999. Effects of stocking density and feeding levels on growth and feed efficiency of Nile tilapia (Oreochromis niloticus L.) fry. Aquaculture Res. 33: 621-626.

El-Sherif, M.S.\& El-Feky, A.M.I. 2009. Performance of Nile tilapia (Oreochromis niloticus) fingerlings. I. Effect of pH. Inter. J. Agric. Biolo., 11: 297-300.

Hepher, B. \& Y. Priguinin. 1981. Commercial Fish Farming with Special Reference to Fish Culture in Israel. John Willey and Sons Inc., New York. 112 p.

Heriyanto, N.M. \& Subiandono, E. 2011. Penyerapan polutan logam berat $(\mathrm{Hg}$, $\mathrm{Pb}$ dan $\mathrm{Cu}$ ) oleh jenis-jenis mangrove. J. Penelitian hutan dan konservasi alam 8(2): 177-188.

Huang, W-B. \& Chiu, T.-S. 1997. Effects of stocking density on survival, growth, size variation, and production of Tilapia fry. Aquacult. Res., 28: 165-173.

Huisman, E.J., M. Breterler \& A. Vismans. 1979. Retention of energy, protein, fat and ashin growing carp (Cyprinus carpio) under different feeding and temperature regimes. Proceeding World Symposium on Fish Nutrition and Fish.

Irwin, S., Halloran, J.O. \&Fitzgerald, R.D. 1999. Stocking density, growth and growthvariation in juvenile turbot, Scophthalmus maximus (Rafinesque). Aquacult., 178: 77-88.

Lovell, T. 1989. Nutrition and Feeding of Fish. An AVI Book, Van Nostrand Reinhold, New York. 260 p.

Kariada, N. \& Irsadi, A. 2014. Peranan Mangrove sebagai biofilter 
pencemaran air wilayah tambak bandeng Tapak, Semarang. J. Manusia dan Lingkungan. $21(2): 188-$ 194

Mardiana, T.Y. \& M.B.Syakirin. 2013. Pemanfaatan lahan sawah puso akibat rob melalui budidaya ikan nikan berbagai strain di Desa Pecakaran kecamatan Wonokertyo Kabpupaten Pekalongan. Laporan penelitian. Fakultas Perikanan Universitas Pekalongan. 35 hal.

Ogunji, J., Toor, R., Schulz, C., \&Kloas, W. 2008. Growth performance, nutrient utilization of Nile tilapia Oreochromis niloticus fed housefly maggot meal (Magmeal) diets. Turkish J. Fish. Aquat. Sci., 8: 141-147.

Papst, M.H., Dick, T.A., Arnason, A.N. \& Engel, C.E. 1992. Effect of rearing density onthe early growth and variation in growth of juvenile Arctic charr, Salvelinus alpinus(L.). Aquacult. Fish. Manag., 23: 41-47.

Pribadi, R., R. Hartati, A. Djunaidi, Sri Redjeki,\& A. Rovia. 2015. Resilience fish assessment. Fakulty of Fisheries and Marine Science, Diponegoro University. Semarang. 16 p.

Ronald, N., Gladys, B., \& Gasper, E. 2014. The Effects of Stocking Density on the Growth and Survival of Nile Tilapia (Oreochromis niloticus) Fry at Son Fish Farm, Uganda. J Aquac Res Development 5: 222 . doi: $10.4172 / 2155-9546.1000222$

Rositasari, R. \& Lestari. 2013. Evaluasi lingkungan perairan pesisir Semarang . Jurnal Ilmu dan Teknologi Kelautan Tropis 5(1): 112-121.

Saha, S.B. \& M.S. Khatun. 2014. Production performance of monosex Nile Tilapia Oreochromis niloticus in brackishwater ponds. Bangladesh J. Zool. 42(2): 261269.

Satuan Kerja Perbenihan dan Budidaya Ikan Air Tawar (SATKER PBIAT) Janti. 2009. Buku Panduan SPO (Standar Prosedur Operasional) Nila Merah Strain Janti "LARASATI" (Oreochromis niloticus). Balai Budidaya Air Tawar. 60 hal.

Sharaf, M.M., Sharaf, S.M., \& El Marakby, H.I. 2004. The effect of acclimatization of freshwater Red Hybrid Tilapia in marine Water. Pakistan J. Biol. Sci. 7(4): 628-632.

Silva, P.C., Souza, V.L., Padua, D.M.C., Dalacorte, P.C. \& Goncalves, D.C. 2000. Effectof stocking density on growth and fillet composition of tetra hybrid red tilapia, Israelistrain. pp. 341345. In: K. Fitzsimmons and J.C. Filho (eds.). Tilapia Aquaculturein the $21 \mathrm{st}$ Century. Proceedings from the 5th International Symposium on TilapiaAquaculture. Vol. 2. 3-7 Sept. 2000 , Rio de Janeiro, Brazil.

Steel, K.G.D. \& J.H. Torrie. 1980. Principles and Procedures of Statistic, Biometrical Approach. McGraw-Hill Book Company, New York. 633 pp.

Susilo, U., W. Meilina, \& S. B. I. Simanjuntak. 2012. Regulasi Osmotik dan Nilai Hematokrit Ikan Nila (Oreochromis sp.) pada medium dengan salinitas dan temperatur air berbeda. Penelitian Hayati. 18:51- 55.

Suyanto, Rachmatun. 2009. Pembenihan dan Pembesaran Nila. Panebar Swadaya. Jakarta.

Uchida, K., Kaneko. T., Yamaguchi, A., Ogasawara. Y., \& Hirano. T., 1997. Reduced hypoosmoregulatory ability and alteration in gill chloride distribution in mature chum salmon (Oncorhynchus keta) migrating upstream for spawning. Mar. Biol. 129: 247-253.

Weatherly A. H. \& Gill H. S. 1987. The Biology of Fish Growth. Academic Press, London.567 pp.

Budihastuti, Rini. 2013 Model dan Strategi Optimasi Pengelolaan Tambak Wanamina Berwawasan Lingkungan di Pesisir Semarang. PhD thesis, Program Doktor IImu Lingkungan. Universitas Diponegoro. 278 hal.

Yakubu,A.F., A. Obi, V.A. Okonji,10.O. Ajiboye, T.E. Adams, E.D. Olaji, \& N.A. Nwogu.2012. Growth Performance of Nile Tilapia (Oreochromis niloticus) as Affected by Stocking Density and Feed Types in Water Flow Through System. World Journal of Fish and Marine Sciences 4 (3): 320-324. DOI: 10.5829/idosi.wjfms.2012.04.03.6230 
Yi, Yang. 2014. A Bioenergetics growth model for Nile Nilapia (Oreochromis niloticus) in a cage-cum-pond integrated culture. Fifteenth Annual Technical Report : South East Asia. Pp. 113- 128. 